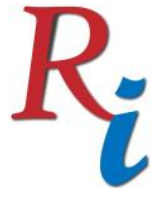

Asia Proceedings of Social Sciences

(APSS)

www.readersinsight.net/APSS

\title{
IDENTIFYING ELEMENTS OF CAREER MANAGEMENT COMPETENCIES IN WORK BASED LEARNING THROUGH \\ SURVEYS OF EXPERTS
}

\section{Hazlina Marwan ${ }^{\star}$}

Faculty of Technical and Vocational Education

Universiti Tun Hussein Onn Malaysia

Malaysia

\section{Azita Ali}

Faculty of Technical and Vocational Education

Universiti Tun Hussein Onn Malaysia

Malaysia

*Corrosponding author's Email: mhazlina75@ gmail.com

Peer-review under responsibility of $3^{\text {rd }}$ Asia International Multidisciplanry Conference 2019 editorial board (http://www.utm.my/asia/our-team/) (C) 2019 Published by Readers Insight Publisher, lat 306 Savoy Residencia, Block 3 F11/1,44000 Islamabad. Pakistan,

info@ readersinsight.net

This is an open access article under the CC BY-NC-ND license (http://creativecommons.org/licenses/by-nc-nd/4.0/). 


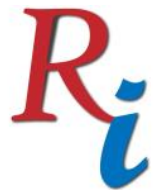

Asia Proceedings of Social Sciences

(APSS)

www.readersinsight.net/APSS

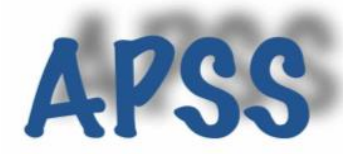

\section{Rese a r ch H i g h I igh t s}

Career management competencies refer to the competencies that will help graduates to identify their existing skills, develop career learning goals and take action to enhance their careers (Neary et al., 2016). These competencies are also crucial for long term career development (Jackson \& Wilton, 2016). However, development of career management competencies requires a higher-order learning process rather than a traditional learning environment (Kuijpers \& Meijers, 2012). In this regard, Work Based Learning (WBL) is recognized as a key driver to provide actual experience at the workplace and an opportunity for learners acquires a broad range of competencies that are highly relevant to their career development. By using Fuzzy Delphi Method (FDM), this study was conducted to identify the elements of career management competencies that can be mastered students based on experts' opinion and consensus. Last of all, the Fuzzy Delphi analysis will interpret a list of career management competencies according to priority based on decision made by expert.

\section{Research Objectives}

Most graduates are not actively considering their future career until they graduate (Perrone \& Vickers, 2003). The report by the Ministry of Higher Education Malaysia (2012) shows that the student's preparation for career exploration, particularly in terms of attitude development, personality and managing career competency still does not meet the need of employers in the job market. There are employers in the industry, who gave negative comments on the graduates and complain about the lack of various graduate's skills which meet the needs of the industry (Rahmat et al., 2012). In addition, most of the graduates have moderate and low level of work readiness (M. Izwan Mahmud et al., 2016). However, this low level of adequacy is not solely due to lack of students' involvement, but also the role of higher education institution itself, which does not equip students with the strategies or capabilities needed to comply with the job requirements (Jackson \& Wilton, 2016). Study by Darche et al. (2009), Jackson and Wilton (2016), and Mari-Hall et al. (2013) demonstrated that learning opportunity in real workplace environments can make an important contribution to enhancing the learner's career progression and can help develop career management skills. Hence, this study aimed to obtain an expert opinion and consensus on the elements of career management competencies in the WBL implementation that can be mastered by polytechnic students.

\section{Methodology}

This research applied the Fuzzy Delphi method (FDM) to obtaining consensus from the panel of experts. Therefore, sixteen experts were selected using purposive sampling method to meet the criteria required in responding to the question of the study. Experts surveyed included academician and industrial experts those selected based on their expertise and experience in the WBL implementation more than 5 years. The first phase of data collection involved document analysis and semi-structured interview with five experts in WBL implementation in polytechnic. Based on the mapping analysis from relevant document analysis and interviews with experts, the researchers gathered the constructs and elements of competencies. In the second phase, experts' opinion was collected using a questionnaire that was developed based on the constructs and elements identified in phase one. This expert questionnaire consists 3 main constructs with 35 elements of competencies. Then, experts required indicating the extent of their agreement using seven point Fuzzy linguistic scale anchored in very strongly disagrees and very strongly agree. Experts were also requested to 


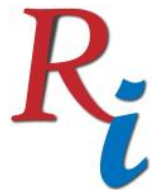

\section{Asia Proceedings of Social Sciences \\ (APSS) \\ www.readersinsight.net/APSS}

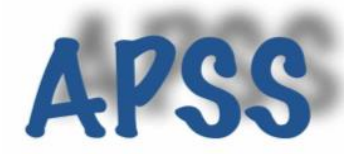

provide suggestions for additional measures and reasons to justify their ideas. The analysis of data was done following using the fuzzy rules which are triangular fuzzy number and process.

\section{Results}

By conducting an expert survey and analyzing the results with the Fuzzy Delphi Method, the elements of competencies were retained and discarded based on the three conditions contained in the triangular fuzzy number, which is the threshold value (d) of each item should not exceed 0.2 , the percentage of agreement exceeding $75 \%$ and the value of each element of exceeding 0.5 (Chang, Hsu \& Chang, 2011; Mohd Ridhuan Mohd Jamil et al., 2017). The results of analysis found that 31 elements from three main constructs of career management competencies: personal management (12 elements), learning and work exploration (8 elements), and career development (11 elements) in line with the FDM condition, and had reached a strong consensus from experts. Meanwhile, there are 4 elements were discarded due to did not meet the fuzzy score requirements. All elements of competencies were ranked from the most to the least important based on the values of the fuzzy score (A) and were refined as recommended by experts.

\section{Findings}

On the whole, the results indicate that the opportunity to gain real work experience through Work Based Learning (WBL) can help students master the various elements of career management competencies. This is in line with M. Kuijpers, Meijers, and Gundy (2011) which explains learning environments that stimulates real work experience does contribute to the use of career management competencies. These elements of competencies are able to mould students into flexible workers as required by the employers. Prior research indicates that emphasis on the development of these competencies will make the students more ready to work and enable them to compete for employment that is commensurate to their skills and abilities. As resulted, this study provided a list of competencies that are crucial for graduate to enable them become a competent and competitive worker.

\section{References}

Chang, P., Hsu, C., Chang, P., 2011. Fuzzy Delphi method for evaluating hydrogen production technologies. International Journal of Hydrogen Energy 36(21), 14172-14179. doi:10.1016/j.ijhydene.2011.05.045

Darche, S., Nayar, N., \& Bracco, K. R. (2009). Work-Based Learning in California: Opportunities and Models for Expansion. Los Angeles.

Jackson, D., \& Wilton, N. (2016). Developing career management competencies among undergraduates and the role of work-integrated learning. Teaching in Higher Education, 21(3), 266-286. doi:10.1080/13562517.2015.1136281

Kuijpers, M., \& Meijers, F. (2012). Learning for now or later? Career competencies among students in higher vocational education in the Netherlands. Studies in Higher Education, 37(4), 449-467. doi:10.1080/03075079.2010.523144

Kuijpers, M., Meijers, F., \& Gundy, C. (2011). The relationship between learning environment and career competencies of students in vocational education. Journal of Vocational Behavior, 78(1), 21-30. doi: 10.1016/j.jvb.2010.05.005

M. Izwan Mahmud, Sidek M. Noah, Jamaludin Ahmad, \& W. Marzuki W. Ahmad. (2016). Modul Kesediaan Kerjaya Berdasarkan Teori Cognitive Information Processing (CIP). Jurnal Kurikulum \& Pengajaran Asia Pasifik, 4(3), 59-75.

Mari-Hall, A., Ulicna, D., \& Duchemin, C. (2013). Work Based Learning: Benefits and Obstacles - A Literature Review For Policy Makers And Social Partners In ETF Partner Countries. European Training Foundation.

Copyright $\odot 2019$ Authors. This is an open access article distributed under the Creative Commons Attribution License, which permits unrestricted use, distribution, and reproduction in any medium, provided the original work is properly cited. 


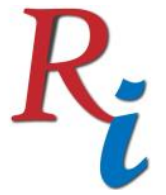

Asia Proceedings of Social Sciences

(APSS)

www.readersinsight.net/APSS

Ministry of Higher Education Malaysia. (2012). The National Graduate Employability Blueprint (2012-2017). Putrajaya, MALAYSIA.

Mohd Ridhuan Mohd Jamil, Saedah Siraj, Zaharah Hussin, Nurulrabihah Mat Noh, \& Ahmad Ariffin Sapar. (2017). Pengenalan Asas Kaedah Fuzzy Delphi Dalam Penyelidikan Rekabentuk dan Pembangunan. (Mohd Ridhuan Mohd Jamil, Ed.). Kuala Lumpur, Malaysia: Minda Intelek Agency.

Neary, S., Dodd, V., \& Hooley, T. (2016). Understanding career management skills: Findings From the First Phase of the CMS Leader Project.

Perrone, L., \& Vickers, M. H. (2003). Life after graduation as a "very uncomfortable world": An Australian case study. Education \& Training, 45(2), 69-78.

Rahmat, M., Ahmad, K., Zainal, N. F. A., \& Idris, S. (2012). Relationship between employability and graduates' skills. International Business Management, 6(4), 440-445. doi:10.3923/ibm.2012.440.445 